\title{
Kemitraan Orangtua: Memperkuat Eksistensi Karakter Islami di Era Revolusi Industri 4.0
}

\author{
Nuraliah Ali' ${ }^{1}$, Jefry Agung Perdana ${ }^{2}$ \\ ${ }^{1}$ Universitas Palangka Raya, Kota Palangka Raya, Indonesia, \\ Email: nuraliahali@law.upr.ac.id \\ 2Universitas Palangka Raya, Kota Palangka Raya, Indonesia, \\ Email: Jeffagungperdana@gmail.com
}

\begin{abstract}
ABSTRAK
Dekadensi moral, pornografi, cyberbullying, hoax, dan ujaran kebencian merupakan realitas negatif yang terjadi pada revolusi industri 4.0. Orang tua perlu mengambil langkah preventif untuk melindungi anak baik dalam keluarga maupun di sekolah. Rekonstruksi kemitraan orang tua di sekolah merupakan kebutuhan untuk memperkuat karakter/akhlak yang mulia pada anak saat ini. Penelitian dengan pendekatan deskriptif kualitatif ini, bertujuan untuk mendeskripsikan bentuk kemitraan orang tua di sekolah dalam menguatkan eksistensi pribadi Islami anak di era revolusi industri 4.0 saat ini. Metode pengumpulan data yang digunakan yakni content document. Tehnik Analisis Data menggunakan tehnik content analysis. Bentuk kemitraan orang tua di sekolah pada saat ini dapat dilakukan dengan 1) penguatan komunikasi dua arah berbasis teknologi informasi, 2) Kelas Orangtua, 3) Komunitas orang tua, 4) Keterlibatan orang tua sebagai motivator dan Inspirator, 5 ) keterlibatan orang tua di Kelas. Pada revolusi industri 4.0, usaha memperkuat keberadaan karakter yang dilandasi nilai-nilai Islami pada anak dapat dilakukan dengan mengikuti lima pilar, yaitu akting moral, moral mengetahui, moral mencintai, moral pemodelan, dan kepatuhan. Melalui lima pilar tersebut diharapkan dapat memperkuat eksistensi karakter anak di era destruktif saat ini.
\end{abstract}

Kata Kunci: Kemitraan Orangtua, Karakter Islami, Revolusi Industri 4.0.

\section{Parental Relationship: Strenghten Eksistence Of Islamic Character In Revolution Industry 4.0}

\begin{abstract}
Moral decadence, pornography, cyberbullying, hoaxes, and hate speech are negative realities that occur in the fourth revolution industry. Parents need to take preventive steps to protect children both in the family and at school. Reconstruction of parent partnerships in schools is a necessity for children's knowledge, competitiveness, and noble character. The research with a qualitative descriptive approach aims to describe the form of partnerships between parents in schools in strengthening the existence of the Islamic personality of children in the current era of the industrial revolution 4.0. The data collection method used is a content document and data analysis techniques using content analysis techniques. The form of a partnership of parents in schools in the fourth industrial era is done by 1) reinforcement of two-way communication based on information technology, 2) Parental Classroom, 3)
\end{abstract}


parents Community, 4) Parent's involvement as motivator and Inspirator, 5) parents 'engagement in Class. In the fourth industrial revolution, strengthen the existence of children's character with Islamic values can be done by following the five pillars, namely moral acting, moral knowing, moral loving, moral modelling, and compunction. Through the five pillars are expected to strengthen the existence of children's character in this disruptive era.

Key Words: Parents Partnership, Islamic Character, Industrial Revolution 4.0.

Article history:

Received: 03-06-2020

Revised: 19-07-2020

Accepted: 27-09-2020

Copyright (c) 2020 Ali, Perdana

\section{PENDAHULUAN}

Peningkatan laju informasi dan pesatnya pengembangan pengetahuan yang disebabkan cyber centred, Internet of Think, dan digitalisasi teknologi informasi merupakan realitas yang dihadapi pada fourth revolution Industry. Pada tahun 2011 dimulai era industri baru yang ditandai meningkatnya konektifitas yang terpusat pada internet yang memberi kemudahan mengakses informasi yang tak berbatas waktu dan tempat.

Menurut Jamal Ma'mur Asmani (2012) efek globalisasi ini memiliki konsekuensi keuntungan dan kekurangan yang seimbang, ibarat pisau yang bermata dua. Nilai positif atau keuntungan yang ditimbulkan oleh globalisasi seperti kompetisi, integrasi, dan kerjasama, sedangkan dampak negatif atau kerugian yang ditimbulkan antara lain lahirnya generasi instan, fenomena dekadensi moral yang banyak terjadi, sikap dan prilaku konsumerisme. Menurut Barnawi dan M. Arifin (2013) bahwa maraknya tindakan kekerasan, tindakan kriminal, bullying, free seks, dan prilaku menyimpang lainnya merupakan dampak negatif yang muncul dari keberadaan globalisasi yang terjadi saat ini.

Era digital memberikan dampak yang luar biasa khususnya pada generasi muda di Indonesia. Pengguna produk digital dan akses internet di Indonesia sebanyak tiga puluh juta orang yang usianya masih tergolong remaja (Kemenkominfo, 2014). Mereka menggunakan internet dengan 
berbagai aktifitas yang bervariasi dan produk digital yang beraneka macam. Selain menawarkan sisi positif yang bermanfaat, teknologi digital juga hadir dengan sisi negatif. Kemudahan mengakses data dan informasi kapan dan dimana saja membuat generasi milenial rawan akan terbawa arus dampak negatif yang merusak nilainilai karakter anak sebagai generasi penerus bangsa dan agama.

\section{Aktifitas}

penggunaan

internet terbanyak ialah pencarian data atau informasi, kemudian disusul penggunaan untuk media sosial, akses musik, dan akses video. Lebih lanjut dipaparkan bahwa dari responden yang menjelajah di media sosial, mereka tidak sungkan berkomunikasi dan menyebarkan informasi pribadi seperti alamat rumah dan nomor kontak dengan orang yang tidak dikenal.

Aktifitas ini tentu akan dimanfaatkan oleh pelaku-pelaku kriminal untuk melakukan tindakan yang melanggar etika, moral, dan hukum yang berlaku demi mendapat keuntungan pribadi. Kurangnya pengetahuan dan pemahaman akan resiko ditindas secara online merupakan salah satu alasan mereka akan menjadi korban penyalahgunaan internet dan teknologi informasi. Pernyataan ini didukung oleh penelitian yang menyebutkan bahwa responden yang menyadari resiko dieksploitasi dan dizalimi secara online hanya sebanyak $42 \%$ responden dan sebanyak 13\% diantaranya merupakan sasaran/objek penyalahgunaan internet (Unicef dan kemenkominfo, 2014).

Melihat fakta tersebut maka sangat penting untuk membekali anak dengan nilai-nilai karakter khususnya nilai-nilai karakter Islami sebagai bekal mereka menghadapi gempuran dampak merusak dari perkembangan teknologi informasi yang terjadi. Pembentukan dan penguatan eksistensi karakter Islami anak di era destruktif ini sangat penting.

Usaha untuk mencegah generasi milenial menjadi korban destruktivitas era digital, tidak cukup hanya dengan memberikan pengetahuan akan penggunaan produk-produk teknologi digital saja, tetapi perlu juga untuk 
menanamkan pentingnya sikap bijaksana dan tanggungjawab dalam menggunakan teknologi itu sendiri (Chandra, 2018). Menanamkan pemahaman dan sikap positif kepada anak untuk menjadi manusia berkarakter akan menjadi bekal sekarang dan nanti di masa akan datang sehingga anak tidak terjerumus dalam dampak negatif dari perkembangan era (Nahriyah, 2017)

Peran aktif wali anak adalah salah satu aspek yang mempengaruhi usaha membentengi anak dari distruptivitas era digital dan dasar pertama dan utama dalam mencetak pribadi anak sejak kecil. Orang tua diharapkan dapat menyiapkan dan mengusahakan keberadaan situasi, kondisi, suasana, dan lingkungan yang kondusif, seimbang, nyaman, tentram, dan tenang sehingga akan mudah dalam menginternalisasikan nilai-nilai positif sebagai persiapan anak menyongsong era digital (Rachman, 2016).

Mengawal tumbuh kembang anak tidak cukup hanya dengan 24 pengawasan dan pendampingan di rumah saja, tetapi orang tua perlu berpartisipasi aktif juga di sekolah dan lingkungan masyarakat. Dukungan dan keterlibatan wali sangat penting dalam keberhasilan pendidikan anak.

Bentuk keterlibatan aktif wali anak dalam mendukung kesuksesan pendidikan diantaranya dengan memberikan pendidikan sesuai dengan minat anak, memenuhi kebutuhan sekolah, mengetahui tumbuh kembang anak di tempat belajar, mendampingi anak belajar, memberi motivasi untuk mencapai cita-cita, menciptakan suasana nyaman di rumah, memberi perhatian dan kasih sayang.

Hanya saja tidak semua orang tua memahami dengan baik akan kontribusi mereka dalam menyukseskan keberhasilan pendidikan anak di sekolah, sehingga mewakilkan tanggung jawab dan tugasnya kepada pihak sekolah. Beberapa studi sebelumnya menunjukan bahwa keterlibatan wali anak dalam proses pembelajaran di kelas mempunyai kontribusi positif untuk menyiapkan anak meraih 
tujuan hakiki pendidikan yakni mencerdaskan tiga ranah kecerdasan. Kemampuan penyesuaian diri anak dalam menghadapi perubahan dan perkembangan era serta pembentukan karakter positif, tidak dapat dilepas dari peranan keterlibatan orangtua pada proses pendidikan di sekolah (Rahman, 2014).

Oleh karena itu kajian/studi mengenai Kemitraan Orang Tua: memperkuat eksistensi karakter Islami anak di Era Revolusi Industri 4.0, dinilai layak dan memiliki nilai plus untuk dikaji lebih lanjut. Adapun fokus kajian pembahasan ialah bagaimana peran kemitraan orang tua di sekolah dalam menguatkan karakter Islami anak di era fourth Industrial saat ini.

\section{METODE}

Jenis penelitian ini merupakan penelitian deskriptif kualitatif dengan menggunakan pendekatan Education dan religious approach. Melalui kajian ini, diharapkan dapat mendeskripsikan bentuk kemitraan orangtua dan sekolah dalam usaha menguatkan karakter anak yang dilandasi nilai- nilai Islam. Metode pengumpulan data yang digunakan dalam penelitian ini yaitu content document.

Dokumen konten bertujuan untuk meneliti secara mendalam isi suatu informasi tentang peran kemitraan orang tua dalam memperkuat eksistensi karakter islami anak di era destruktif yang ditulis atau dicetak di jurnal, buku, artikel di media massa dengan menggunakan teknik pengkodean simbol, perhatikan simbol atau pesan secara sistematis, kemudian diberikan interpretasi atau kesimpulan.

Dokumen konten dilakukan dengan cara menganalisis informasi, sintesis informasi, menemukan substansi melalui pemusatan perhatian pada hasil temuan, meringkas substansi temuan konten dan tahap akhir ialah mengambil kesimpulan dari suatu konten/ isi dokumen tersebut. Metode dokumen konten memiliki kesamaan dengan metode tinjauan literatur yang mengkaji berbagai literatur ilmiah, baik dalam bentuk buku, majalah, buletin, surat kabar, dan sebagainya yang relevan dengan 
masalah penelitian meliputi subjek, objek, lingkungan, kondisi sosial dan hubungan penelitian dengan penelitian-penelitian yang telah ada sebelumnya (Afifuddin, 2012).

Adapun Teknik Analisis Data menggunakan teknik analisis content document atau content analysis. Analisis isi merupakan " $a$ procedure that permit scientists to review people behaviour in a backhand manner, through an investigation of their correspondence" (Frankel, 2006). Konten isi memungkinkan peneliti untuk mempelajari pola prilaku manusia secara tidak langsung pada koresponden mereka.

Penelitian ini menggunakan analisis data qualitative content analysis untuk mengetahui bentuk kemitraan orang tua dalam memperkuat karakter yang dimiliki anak di era digital saat ini. Tahapan penelitian dimulai pengumpulan dokumen-dokumen yang memiliki keterkaitan dengan isi penelitian baik dalam bentuk buku, majalah, buletin, surat kabar, dan sebagainya yang terkait/ relevan. Selanjutnya ditelaah melalui tahap kategorisasi dan disajikan dalam kata-kata dan tema, yang bertujuan 26 untuk menggambarkan beberapa interpretasi hasil penelitian.

\section{HASIL DAN PEMBAHASAN}

\section{A. Peran Kemitraan Orangtua di Sekolah pada era Fourth Industri.}

Sekolah dianggap sebagai rumah kedua untuk anak dan remaja setelah kehidupan di lingkungan keluarganya. Sekolah memiliki peran strategis dalam hal pendidikan anak setelah pendidikan keluarga. Sekolah berperan sebagai wadah dalam mengembangkan kemampuan dan kompetensi anak agar dapat mengemban peran sosial dalam kehidupan bermasyarakat. Kemampuan yang dimaksud meliputi aspek kognitif, psikomotorik, afektif, dan moral. (Kuntoro, 2010).

Sekolah di era revolusi industri ini memiliki tantangan yang sangat besar. Sekolah dituntut untuk dapat menghasilkan output berkualitas dan mampu berkarya, mampu beradaptasi dengan dunia digital dan perkembangan teknologi, dan lebih utama tetap memastikan karakter peserta didiknya tidak tergerus arus destruktif era baru. 
Dalam memenuhi tantangan perkembangan zaman dibutuhkan inovasi baru yang kritis dan menggunakan paradigma baru. Penggunaan pola pikir lama dalam menanggapi suatu permasalahan yang kekinian, maka hasil yang akan diperoleh ialah kegagalan (Tilaar: 1998).

Paradigma pendidikan di era fourth industry ditunjukkan oleh gambar 1.

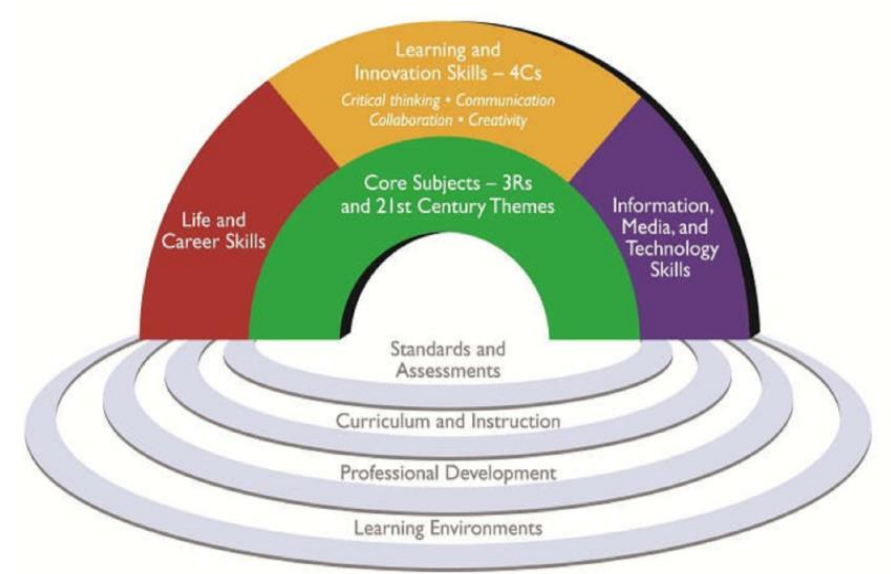

Gambar 1. Framework P-21

Paradigma pendidikan saat ini menginginkan anak/siswa untuk dapat memiliki kriteria inti pendidikan abad milenial, berupa pengetahuan akan teknologi, skill mengoperasikan produk digital, pengetahuan akan media dan informasi, inovasi keterampilan pembelajaran, serta memiliki keterampilan dalam hidup dan karir. Selain siswa yang dituntut memiliki kemampuan digital, pendidik juga diharapkan dapat memiliki kompetensi dan skill berupa pengembangan profesional, pengembangan pengelolaan pembelajaran, dan pengelolaan lingkungan sehingga anak dapat berhasil dalam hidup dan pekerjaannya. Karakteristik, kompetensi, wawasan dan latar belakang pendidik memegang peranan penting dalam pengelolaan pembelajaran dan pembentukan karakter siswa (Ali \& Tanasy, 2018).

Besarnya tanggungjawab sekolah beserta komponenkomponen di dalamnya, tentu tidak akan terlaksana dengan baik jika hanya diserahkan pada orangtua atau pendidik saja. Pihak sekolah dituntut untuk dapat bersinergi dengan pihak-pihak terkait termasuk pihak keluarga yakni wali/orang tua. Orang tua dalam memutuskan keterlibatannya dalam proses pendidikan anaknya di sekolah dapat ditentukan oleh beberapa hal. Rahman (2014) menyebutkan bahwa terdapat beberapa faktor yang mendorong 
orangtua/wali untuk berpartisipasi dan mengambil peran di sekolah. Adapun faktor-faktor tersebut diantaranya ialah aspek kepercayaan, aspek sosial, aspek perbedaan latarbelakang budaya dan aspek psikologis. Kepercayaan orang tua bahwa keterlibatan dan keberadaan mereka di sekolah merupakan hal penting dan akan mempengaruhi tingkat keberhasilan anak mereka.

Peran orangtua/wali dalam pendidikan di sekolah juga dilandasi tujuan memberikan dukungan psikologi pada pencapaian kesuksesan belajar dan pembentukan pribadi anak. Faktor psikologis berupa semangat, tekad, motivasi, dan perilaku anak yang merupakan faktor penting menyangkut tahapan pendidikan dan pembentukan karakter. Kesadaran akan kompetensi individu, perhatian, dan attitude dalam belajar, kemampuan beradaptasi di sekolah, serta kesadaran akan pentingnya pendidikan, merupakan beberapa aspek psikologis yang mempengaruhi pembelajaran anak (Englund, dkk. 2004).
Langkah strategis pihak sekolah dalam menghadapi destruktivitas pendidikan 4.0 saat ini dapat dilakukan dengan membangun kemitraan dengan orang tua di sekolah. Melihat Fenomena dan dampak destruktif dari pesatnya teknologi informasi berbasis internet dan digital saat ini, maka orang tua perlu untuk mengambil langkah membentengi anak di dalam lingkungan keluarga maupun di lingkungan sekolah. Rekonstruksi kemitraan orang tua di sekolah bukan hanya sekedar himbauan saja melainkan menjadi kebutuhan demi mencetak anakanak yang berilmu, berdaya saing dan berkarakter mulia.

\section{B. Bentuk Kemitraan Orangtua di Sekolah pada era Revolusi Industri 4.0}

Organisasi yang mewadahi kemitraan orangtua dengan pihak sekolah di Indonesia disebut dengan komite sekolah. Komite ini memiliki kedudukan strategis dalam mengakomodir partisipasi orangtua/wali dan masyarakat dalam sistem pendidikan di lingkungan sekolah. Melalui keterlibatan orangtua/wali melalui 
komite diharapkan mampu menumbuhkan sikap merasa memiliki terhadap sekolah, sehingga orangtua juga dapat memberikan sumbangsih pemikiran dalam membuat kebijakan demi pendidikan yang bermutu dan memberikan kontribusi dalam pengelolaan kelembagaan yang baik, andal, dan terpercaya demi mencapai tujuan pendidikan secara bersama-sama (Mas, 2013).

Bentuk-bentuk kemitraan orang tua dengan sekolah di era pendidikan 4.0 dapat dilakukan sebagai berikut:

\section{Penguatan Komunikasi dua arah berbasis Teknologi Informasi}

Kemitraan antara pihak sekolah dan orangtua/wali dapat terjalin dengan baik jika didukung oleh komunikasi informasi dua arah yang kapabel. Oleh karena itu, dinilai penting untuk merancang suatu strategi, langkah dan kebijakan yang mampu diterapkan sebagai usaha penguatan komunikasi dua arah antara sekolah dan orangtua. Menurut Andriani (2015), komunikasi merupakan usaha menyampaikan informasi pesan berupa gagasan, ide pemikiran, dan materi belajar dari satu komunikan ke komunikan yang lain agar terjadi timbal balik di antaranya keduanya. Lebih lanjut dijelaskan bahwa komunikasi merupakan proses sosial yang dilakukan dengan menggunakan simbol dalam usaha menginterpretasikan makna (Ardianto \& Bambang: 2009) dan bertujuan untuk mengubah perilaku individu lain (Zulkarnain: 2013).

Komunikasi memiliki peran yang strategis antara guru dan siswa serta antara sekolah dengan orangtua/wali. Dalam konteks kehidupan sekolah, informasi perkembangan anak dari pihak keluarga kepada sekolah dan sebaliknya dapat diperoleh hanya jika komunikasi dua arah yang baik terjalin diantara kedua pihak.

Secara umum, komunikasi pihak sekolah khususnya guru dengan orangtua hanya terjadi secara formal melalui pertemuan atau kegiatan yang diselenggarakan oleh sekolah yang lazimnya hanya dilakukan sekitar empat kali dalam setahun, seperti rapat komite, penerimaan rapor 
hasil belajar, rapat-rapat dengan agenda penting. Sementara guru dan orangtua/wali siswa jarang mengkomunikasikan hal-hal yang esensial mengenai perkembangan siswa baik minat belajar, sikap dan prilaku siswa di sekolah, disiplin, pergaulan, kemajuan prestasi, dan masalah yang dihadapi siswa.

Proses komunikasi interpersonal yang dinamis antara guru dan orangtua/wali anak dapat mengacu pada model komunikasi sirkuler Osgood dan Schramm (dalam Mulyana 2002), sebagaimana ditunjukkan oleh gambar 2 berikut ini:

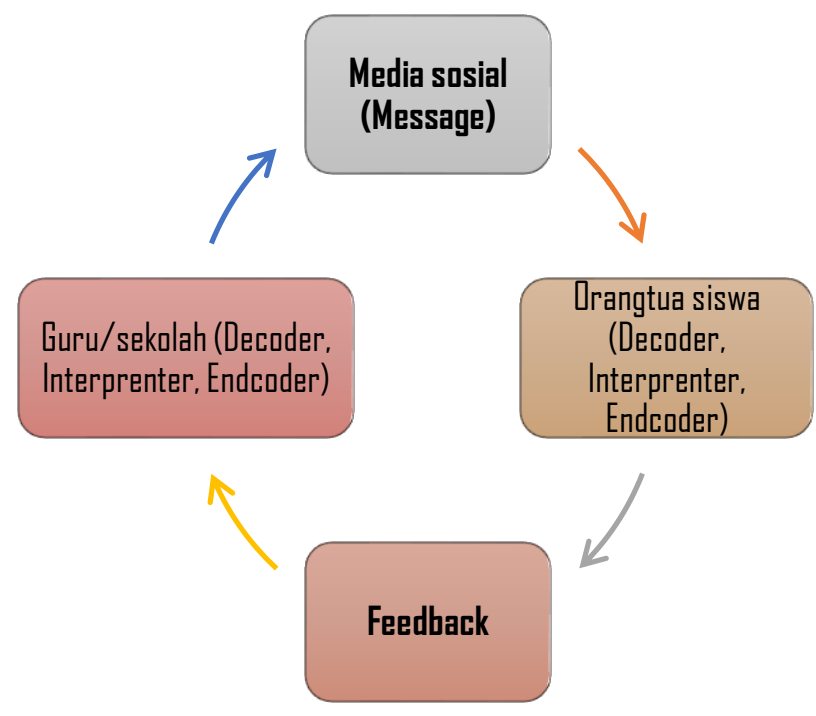

Gambar2. Model komunikasi sirkuler Osgood dan Schramm

Proses komunikasi yang dinamis pada interpersonal communication saling berkaitan 30 menciptakan interaksi dua arah dengan menggunakan media sosial menjadi media komunikasi. Relasi pendidik dan orangtua anak lebih dipusatkan pada interaksi kerjasama pada kegiatan-kegiatan pengawasan, pengontrolan, dan lain-lain dalam usaha mendapatkan hasil belajar yang baik dan memastikan pembentukan karakter anak ke arah yang positif.

Dengan adanya penguatan perkembangan teknologi informasi saat ini, diharapkan akan membantu guru dan orangtua untuk mengkonstruksi jalinan komunikasi timbal-balik yang efektif dan efisien. Bentuk media komunikasi berbasis TIK diantaranya ialah komunikasi melalui pesan singkat (SMS), telepon seluler, email atau media sosial yang populer seperti whatsap, facebook, instagram, twiter, messenger dll. Media-media tersebut terkenal dan banyak orang dari berbagai kalangan yang menggunakan, sehingga dapat diberdayakan sebagai sarana komunikasi yang familiar, simple, efektif, efisien, dan terjangkau.

\section{Parental Classroom}


Kesadaran orangtua akan pentingnya menyiapkan lingkungan yang kondusif dan kesediaan mendampingi anak belajar di rumah dapat diusahakan melalui kegiatan kemitraan parental classroom. Pendidikan orang tua melalui parental classroom ini dapat dilakukan di dalam kelas orangtua/wali dan dijadwalkan secara berkelanjutan oleh pihak sekolah atau komite orangtua (Kemdikbud, 2016).

Parental classroom ini diharapkan dapat membantu orangtua/wali anak untuk:

a. Mendapatkan gambaran konkret mengenai kondisi perkembangan anak di sekolah dan usaha yang dapat dilakukan orangtua dalam mendampingi perkembangan tersebut;

b. Menumbuhkan kesadaran akan pentingnya peran positif dan tanggungjawab orangtua dalam mengatasi permasalahan pembelajaran anak baik di sekolah maupun di rumah;

c. Mendapatkan saran, solusi dan bantuan akan permasalahan anak melalui kerja sama yang sinergis dan harmonis antara orangtua siswa dan pihak sekolah.

Parental classroom diarahkan untuk memberi pengetahuan dan wawasan kepada orangtua sehingga dapat memaksimalkan perannya sebagai:

a. Adviser (Penasihat)

Orangtua memikul tanggungjawab terhadap kebutuhan fisik dan psikis anaknya. Orangtua dituntut menjadi seorang adviser yang diharapkan dapat memberi perhatian akan kebutuhan harian, pendidikan, materiil, dan sosial anak, serta menjadi teladan yang menampilkan nilai-nilai positif kehidupan bagi anaknya. Dalam pergaulan sehari-hari, anak sering menemui permasalahan pribadi maupun sosial sehingga orangtua diharapkan dapat memberikan nasihat dan solusi yang mendidik kepada anaknya sehingga terhindar dari hal-hal negatif (Ahmadi, 2004).

b. Motivator

Menurut Slameto (2003), orangtua memiliki tugas untuk selalu memberikan motivasi dan dorongan kepada anaknya dalam menjalani proses pendidikan baik 
di rumah maupun di sekolah. Orangtua diharapkan selain memberikan nasihat atau mendampingi aktifitas belajar anak di rumah, juga diharapkan mampu memberikan dorongan agar anak lebih termotivasi menjalani proses pendidikannya. Jika orang tua terlibat langsung dalam pembelajaran anaknya dan mendapat dukungan psikologis, maka akan berdampak kepada semangat anak untuk meningkatkan prestasinya di sekolah (Isnawati, 2012; Mawarsih, 2013; Ningsih, 2016).

c. Fasilitator Belajar

Orangtua bertanggung jawab dalam pembelajaran anak di rumah. Penyediaan kebutuhan anak akan fasilitas belajar saat di rumah seperti ruang belajar yang kondusif, tersedianya prasarana seperti meja, kursi, internet, wifi, komputer, laptop, referensi buku, dll merupakan tanggungjawab orangtua sebagai fasilitator belajar (Suharsono, 2004). Tersedianya fasilitas belajar merupakan salah satu faktor pendukung pencapaian prestasi anak di sekolah. Hal ini didukung oleh sejumlah hasil studi yang menyebutkan bahwa terdapat 32 pengaruh antara fasilitas belajar dan prestasi belajar (Sunadi, 2013; Retnowati, 2016; Sholeh, 2018)

d. Pendamping

Menurut Suharsono (2003) Saat Belajar di Rumah orang tua diharapkan dapat menemani, mendampingi, memberi nasihat dan motivasi kepada anak. Perhatian orangtua terhadap anak, baik berupa penyediaan fasilitas belajar, melakukan pengawasan dalam belajar, pengecekan nilai secara berkala, mendampingi saat belajar dan memberi teladan/ contoh dalam berprilaku, akan berdampak positif dalam pembelajaran anak. Perhatian tersebut akan menanamkan dalam benak anak bahwa mereka diperhatikan orangtuanya dan anak merasa disayangi di rumah. Perasaan yang tertanam dalam benak anak tersebut akan membantu anak dalam proses pendidikannya.

\section{Parents Community}

Parents Community atau komunitas orangtua/wali anak di tingkat kelas dibentuk agar semua orangtua dapat berkontribusi secara aktif pada setiap program kemitraan. Menurut kemendikbud 
(2016), bahwa melalui Parents Community ini pihak sekolah berperan sebagai:

a. Sosialisator yang bertugas mengkomunikasikan berbagai program kegiatan kemitraan kepada orangtua. Melalui kegiatan tersebut diharapkan orangtua memperoleh pemahaman dan termotivasi untuk dapat terlibat dan berperan aktif untuk program pendampingan

b. Identifikator yang berperan untuk mendata/ identifikasi orangtua yang berpartisipasi aktif dan yang pasif serta mengetahui penyebab dan alasannya. Dengan adanya identifikasi tersebut, pihak sekolah memiliki data awal sebagai dasar untuk mendiskusikan dengan orang tua lain dan untuk menemukan solusi atas berbagai permasalahan yang dihadapi orangtua dalam menjalankan perannya dan permasalahan anak dalam belajar

c. Inisiator yang menginisiasi program-program kemitraan dan berkomunikasi dengan orangtua mengenai progress pendidikan siswa di sekolah

d. Motivator yang berperan untuk membangun komunikasi antara sekolah dengan orang tua sehingga terwujud keselarasan dalam pola mendidik anak, pendampingan pengasuhan, pembimbingan, dan pengawasan

\section{Pelibatan orang tua sebagai motivator dan inspirator}

Sekolah melibatkan orangtua siswa yang berasal dari berbagai latarbelakang pendidikan dan pekerjaan untuk saling membagikan pengalaman dan pengetahuannya di dalam suatu kegiatan, diharapkan dapat membuka pintu interaksi positif untuk saling memberikan motivasi dan inspirasi satu sama lain.

Berbagai hasil penelitian menunjukan adanya pengaruh motivasi dan perhatian orang tua terhadap karakter anak (Subianto, 2013; Anisa, 2017; Antasari, 2020). Perhatian, kasih sayang, motivasi, dan keamanan yang diberikan oleh orang tua secara langsung mempengaruhi pembentukan karakter anak sejak dini. Oleh karena itu, dalam usaha 
pembentukan karakter anak di era revolusi industri 4.0, pihak sekolah hendaknya menjalin kemitraan dengan orang tua dengan menumbuhkan kesadaran setiap orangtua untuk dapat memaksimalkan perannya sebagai motivator utama dan pertama bagi anak-anak mereka.

\section{Pelibatan orang tua dalam kelas}

Bentuk kegiatan yang melibatkan orangtua dalam kelas seperti kegiatan mengamati tahapan-tahapan pembelajaran yang sedang berlangsung dan sekaligus membantu kegiatan belajar anak. Pelibatan orang tua di kelas diharapkan dapat membantu dalam proses pembelajaran dan menumbuhkan spirit, minat, dan semangat siswa. Selain itu juga dapat mendorong dalam usaha menanamkan dan menumbuhkan sikap positif pada anak.

\section{Menurut Kemendikbud} (2016), adapun bentuk kegiatan partisipasi orang tua dalam kelas meliputi kegiatan keikutsertaan orangtua dalam rangkaian proses pembelajaran, kegiatan mengawasi jalannya pembelajaran, memberikan masukan mengenai 34 proses pembelajaran, dan program sukarela untuk belajar di rumah dan di tempat lain yang disepakati bersama.

$$
\text { Bentuk aktifitas }
$$

keikutsertaan orangtua dalam kelas dikenal dengan inspiration class. Menurut Yohanes (2018), kelas inspirasi merupakan kegiatan yang menghadirkan orangtua yang berasal dari latar belakang profesi yang berbeda untuk menjadi pembicara di dalam kelas. Dalam kelas inspirasi anak-anak akan diajak untuk menyimak penjelasan para orangtua mengenai profesi atau pekerjaan yang dilakukannya serta memberikan cerita-cerita inspiratif sehingga anak termotivasi untuk meningkatkan prestasi belajar.

Kehadiran orangtua dalam kelas sebagai penyaji di depan anak-anak maka akan menumbuhkan kebanggaan anak terhadap orangtua mereka masingmasing dan bagi orangtua dapat mengenal rekan sekelas anaknya. Melalui kelas inspirasi diharapkan anak akan belajar untuk menghargai, menghormati, dan menginspirasi pekerjaan orangtua rekannya yang lain. Hal ini 
bertujuan untuk menumbuhkan rasa kekeluargaan dan keakraban di kelas, membangkitkan minat dan semangat anak untuk giat belajar serta membantu anak mulai bermimpi dan memiliki cita-cita di masa akan datang.

Menurut Harususilo (2018) bahwa keterlibatan orangtua di kelas untuk mengenalkan profesi mereka dan memberikan kisahkisah inspiratif akan membekas dan tertanam dalam ingatan atau memori anak dalam jangka waktu yang lama. Anak akan menganggap hal tersebut sebagai bentuk dukungan orangtuanya kepada mereka. Tentunya dukungan orangtua tersebut akan menjadi motivasi yang besar kepada anak untuk lebih semangat meraih prestasinya.

\section{Eksistensi nilai karakter islami anak di Era Revolusi 4.0 melalui kemitraan orang tua di sekolah.}

Era revolusi industri 4.0 memiliki keuntungan, manfaat dan kontribusi yang sangat besar dan luas pada segala sektor kehidupan. Akan tetapi akan menjadi sebuah ancaman bagi kehidupan jika manusia tidak bijak dalam menghadapinya. Era dengan kemudahan akses internet memberikan akses informasi berupa tontonan film, video, gambar yang tidak layak bagi peserta didik yang masih dalam tahap pembentukan karakter dan pencarian jati diri.

Disrupsi yang disebabkan oleh era industri mampu menimbulkan degradasi moral semakin banyak terjadi. Internet yang menghubungkan sang anak pada dunia digital memiliki kemampuan untuk mempengaruhi karakter pribadi anak (Iswan \& Herwina, 2018). Dunia maya memiliki gangguan yang tidak terlihat tetapi secara nyata memiliki pengaruh yang signifikan yang mampu melemahkan eksistensi karakter anak khususnya karakter yang berlandaskan nilai-nilai Islami. Oleh karena itu perlu langkah pasti dalam mengantisipasi bahaya disrupsi demi eksistensi karakter Islami anak saat ini.

Dalam usaha membentuk dan mempertahankan eksistensi karakter yang dilandasi nilai-nilai Islam yang sesuai syariat, Rasulullah SAW telah memberikan 
pedoman dan mencontohkannya secara langsung. Pembentukan karakter Islami, tidak cukup hanya dengan memberikan pengetahuan dan pemahaman akan makna yang baik dan benar saja, dan kemudian mengharapkan perubahan yang luar biasa, tetapi diperlukan pula pemberian motivasi, dorongan, dan teladan yang baik, pembiasaan, latihan yang berkelanjutan, serta persepsi terhadap pengalaman hidup, diharapkan dapat menumbuhkan keinginan yang kuat dalam diri anak untuk melakukan perubahan secara positif (Dewi, 2012).

Sekolah juga dapat menginternalisasikan nilai-nilai karakter positif seperti toleransi, keadilan, kesetaraan, menghormati setiap perbedaan dan menjunjung persamaan hak asasi manusia yang melalui pengembangan pendidikan berbasis multikultur. Pengembangan pendidikan Islam berbasis multikultur merupakan salah satu pilihan, respon, tanggapan akan tantangan modernisasi dan globalisasi (Ali \& Noor, 2019).

Orangtua/wali mempunyai andil yang besar dalam mendorong 36 terciptanya kondisi psikologis anak untuk menjaga karakter islami yang dimiliki. Nilai-nilai kehidupan yang dilandasi al Qur'an dan hadits pertama kali dikenal anak melalui orangtuanya. Anak belajar akan saling mengasihi dan menyayangi melalui orangtua yang menunjukan kasih sayang mereka kepada anakanaknya. Anak mengetahui nilai kejujuran ketika orang tuannya mengajarkan kejujuran. Membangun pondasi karakter anak yang positif tidak dapat dilepaskan dari cara mereka mengamati karakter-karakter positif yang ada di sekitar mereka (Hyoscyamina \& Dewi, 2012)

Upaya untuk menanamkan karakter islami terhadap anak dan membiasakan anak untuk melakukan kebaikan harus dilaksanakan secara berkelanjutan dan bersungguh-sungguh. Orangtua memiliki pengaruh yang besar dalam pembentukan karakter pada anak. Orang tua yang secara konsisten dalam berprilaku seperti yang diajarkan Rasulullah SAW dapat menggetarkan kata hati anak untuk mengimitasi prilaku tersebut dan mengidentifikasi prilaku 
tersebut untuk menjadi bagian dari pribadinya sehingga menjadikan pribadi yang berkarakter positif (Shochib, 2010).

Menurut Arief (2019) usaha untuk membentuk dan mempertahankan eksistensi karakter islami anak di era fourth revolution industry saat ini dapat dilakukan dengan mengikuti 5 rukun pembentukan karakter yakni:

Pertama, Moral Acting yaitu prilaku positif yang dilakukan dengan cara pembiasaan dan pembudayaan.

Melakukan tindakan kebaikan secara berkelanjutan akan memberikan habituasi pada pikiran, keyakinan dan keinginan untuk dapat menyenangi tindakannya sehingga dapat menjadi karakter jika dilaksanakan dalam jangka waktu yang lama.

Kedua, Moral knowing atau membelajarkan pengetahuan tentang nilai-nilai yang baik. Kemampuan orangtua dalam mengkomunikasikan kepada anaknya mengenai pemahaman nilai baik dan buruk, benar dan salah menurut tuntunan syariat Islam, akan membuat anak mengerti apa yang harus mereka perbuat dan menyadari pentingnya untuk mengubah perbuatannya yang salah serta mengoptimalkan perbuatannya yang baik. Orangtua perlu mengenalkan dan memberi pengetahuan dan pemahaman nilai-nilai akhlak kepada anaknya sebagai pijakan dan koridor prilaku anak yang nantinya akan membentuk karakter anak itu sendiri.

Ketiga, Moral loving atau merasakan dan mencintai yang baik. Esensi kehidupan yang harmonis berlandaskan nilai-nilai Islami dalam keluarga akan membantu anak untuk merasakan keterikatan dan kasih sayang diantara anggota keluarga. Hal tersebut merupakan dasar lahirnya pola pikir positif pada anak terhadap nilai-nilai akhlak Islami seperti berbuat baik dan merasakan manfaat dari kebaikan tersebut, bersikap jujur dan mengetahui konsekuensi jika tidak jujur, dan berbagai akhlak terpuji lainnya.

Keempat, moral modelling atau keteladanan. Hidayatullah (2010) menyatakan bahwa pembinaan dan pembentukan 
karakter dapat terlaksana dengan teladan dan mendidik hati sebagai pilarnya. Orangtua merupakan figur contoh yang memberikan pengaruh besar bagi prilaku anak karena mereka merupakan orang terdekat secara emosional. Orang tua dituntut untuk berupaya memiliki sikap seperti yang dicontohkan Rasulullah SAW seperti amanah, fathonah, shiddiq, ikhlas, sabar adil, berbakti kepada orang tua, bertanggungjawab, dan masih banyak akhlak karimah lainnya. Anak yang memiliki karakter Islami diawali dari mengimitasi prilaku orang yang paling dekat dengannya secara psikologis yang selanjutnya melakukan identifikasi terhadap prilaku tersebut untuk dijadikan modal membentuk karakternya.

Karakter anak yang diimitasi dari lingkungan keluarganya akan semakin dikuatkan dengan nilainilai yang mereka peroleh pada lingkungan sekolah dan masyarakat. Dengan demikian, pendidik dan orangtua perlu membantu anak dalam memilih dan menetapkan lingkungan eksternalnya agar anak dapat terhindar dari pengaruh negatif perkembangan zaman.

\section{KESIMPULAN}

1) Bentuk kemitraan orang tua di sekolah pada saat ini dapat dilakukan dengan 1) penguatan komunikasi dua arah berbasis teknologi informasi, 2) Kelas Orangtua, 3) Komunitas orang tua, 4) Keterlibatan orang tua sebagai motivator dan Inspirator, 5 ) keterlibatan orang tua di Kelas.

2) Pada revolusi industri 4.0, usaha memperkuat keberadaan karakter yang dilandasi nilainilai Islami pada anak dapat dilakukan dengan mengikuti lima pilar, yaitu akting moral, moral mengetahui, moral mencintai, moral pemodelan, dan kepatuhan.

\section{DAFTAR PUSTAKA}

Afifuddin. 2014. Metodologi Penelitian Kualitatif, bandung: Pustaka Setia.

Anisah, A. S. 2017. Pola asuh orang tua dan implikasinya terhadap pembentukan karakter anak. Jurnal Pendidikan UNIGA, 5(1), 7084. 
Ali, N., \& Noor, S. 2019. Pendidikan Islam Multikultur: Relevansi, Tantangan, dan Peluang. Jurnal Hadratul Madaniyah, 6(1), 24-42. https://doi.org/10.33084/jh m.v6i1.879

Ali, N. A., \& Tanasy, N. 2018. Analisis Kinerja Guru PAI dalam Penerapan Metode Prompts pada Penyandang Disabilitas di SLB A Yapti Makassar. Inspiratif

Pendidikan, 7(2), 207-218. https://doi.org/10.24252/ip .v7i2.7854

Ahmadi, A., \& Supriyono, W. 2004. Psikologi Belajar. Jakarta: PT. Rineka Cipta

Asmani, J. M. 2012. Manajemen Sekolah. Jogjakarta: Diva Press.

Barnawi, \& Arifin, M. 2012. Etika \& Profesi Kependidikan, Yogyakarta: Ar-Ruz Media.

Pratama, D. A. N. 2019. Tantangan Karakter Di Era Revolusi Industri $4.0 \quad$ Dalam Membentuk Kepribadian Muslim. Al-Tanzim: Jurnal Manajemen Pendidikan Islam, 3(1), 198-226. https://doi.org/10.33650/al -tanzim.v3i1.518

Ardianto, E., \& Anees, B. Q. 2007. Filsafat Ilmu

Komunikasi. Bandung:

Simbiosa Rekatama Media.

Englund, M. M., Luckner, A. E., Whaley, G. J., \& Egeland, B. 2004. Children's achievement in early elementary school: Longitudinal effects of parental involvement, expectations, and quality of assistance. Journal of Educational Psychology, 96(4), 723. https://doi.org/10.1037/00 22-0663.96.4.723

Fraenkel, J. R., Wallen, N. E., \& Hyun, H. H. 1993. How to design and evaluate research in education (Vol. 7). New York: McGraw-Hill.

Harususilo, Y.E. 2018. Pelibatan Orangtua dalam Kelas Inspirasi. Kompasnews, https://edukasi.kompas.co $\mathrm{m} / \mathrm{read} / 2018 / 12 / 20 / 23572$ $591 /$ pelibatan-orangtuadalam-kelasinspirasi. diakses pada April 2020.

Hyoscyamina, D.E., Dewi, K.S., 2012. Pengembangan program parenting bagi anak usia dini dengan pendekatan psikologi positif dan karakter Islami. Prosiding Seminar Nasional Psokologi Islami.

Isnawati, N., \& Setyorini, D. 2012. Pengaruh Perhatian Orang Tua dan Motivasi Belajar Siswa terhadap Prestasi Belajar Akuntansi pada Kompetensi Mengelola Dokumen Transaksi Siswa Kelas X Program Keahlian Akuntansi SMK Cokroaminoto 1 Banjarnegara Tahun Ajaran 2011/2012. Jurnal Pendidikan Akuntansi Indonesia, 10(1). https://doi .org/10.21831/jpai.v10i1.92 0 
Iswan, I., \& Bahar, H. 2018. Penguatan Pendidikan Karakter Perspektif Islam dalam Era Millenial IR. 4.0. In Prosiding Seminar Nasional Pendidikan (Vol. 1, No. 1).

Kemdikbud. 2016. Kemitraan Sekolah dengan Keluarga dan Masyarakat. Jakarta: Direktorat Jendral

Pendidikan Anak Usia Dini dan Pendidikan Masyarakat.

Kemenkominfo. 2014. Riset Kominfo dan UNICEF Mengenai Perilaku Anak da Remaja dalam Menggunakan Internet. Diakses pada 28 September 2019, KOMINFO: https://kominfo.go.id

Keyes, C. R. 2002. A Way of Thinking about Parent/Teacher Partnerships for Teachers Le partenariat parent/enseignant: Un autre point de vue Una forma de reflexionar sobre la asociacio ${ }^{\circ}$ n Padre/Maestro para maestros. International

journal of early years education, 10(3), 177-191. https://doi.org/10.1080/09 66976022000044726

Mas, S. R. 2013. Partisipasi Masyarakat dan Orang Tua dalam Penyelenggaraan Pendidikan. El-hikmah, 8(2).

Mawarsih, S. E., \& Hamidi, N. 2013. Pengaruh perhatian orang tua dan motivasi belajar terhadap prestasi belajar siswa sma negeri jumapolo. Jupe-Jurnal Pendidikan Ekonomi, 1(3).
Mulyana, D. 2002. Imu Komunikasi Suatu Pengantar. Bandung: PT. Remaja Rosdakarya.

Nahriyah, S. 2017. Tumbuh Kembang Anak di Era Digital. Risalah: Jurnal Pendidikan dan Studi Islam, 4(1).

Ningsih, R., \& Nurrahmah, A. 2016. Pengaruh Kemandirian Belajar dan Perhatian Orang Tua terhadap Prestasi Belajar Matematika. Formatif: Jurnal Ilmiah Pendidikan MIPA, 6(1). http://dx.doi.org /10.30998/formatif.v6i1.754

Rahman, B. 2014. Kemitraan Orang Tua Dengan Sekolah dan Pengaruhnya Terhadap Hasil Belajar Anak. Jurnal Pendidikan Progresif, 4(2).

Retnowati, S. 2016. Hubungan Fasilitas, Kemandirian, dan Kecemasan Belajar terhadap Prestasi Belajar Matematika pada Siswa Kelas VIII SMP di Kecamatan Puring Tahun Pelajaran 2015/2016. EKUIVALEN: Jurnal Pendidikan Matematika, 23(2).

Setiawan, J. A., Suparno, Sahabuddin, C., Tasrif, \& Ramadhan, S. 2020. The Role of Parents on the Character Education of Kindergarten Children Aged 5-6 Years in Bima. Universal Journal of Educational Research 8(3). DOI:

10.13189/ujer.2020.080307

Sholeh, B., \& Sa'diah, H. 2018. Pengaruh Motivasi Belajar 
Dan Fasilitas Belajar Terhadap Prestasi Belajar Ips Siswa Smp Nurul Iman Parung Bogor Tahun Ajaran 2017/2018. Pekobis: Jurnal Pendidikan, Ekonomi, dan Bisnis, 3(2). http://dx.doi.or g/ 10.32493/pekobis.v3i2.P1 2-19.2041

Slameto. (2003). Belajar dan FaktorFaktor Yang Mempengaruhi. Jakarta: PT. Rineka Cipta.

Sodiq, A. K. 2010. Kemitraan Sekolah Workshop Strategi Pengembangan Mutu Sekolah Bagi Kepala Sekolah dan Pengawas Sekolah, Program Pascasarjana Universitas Negeri Yogyakarta.

Subianto, J. 2013. Peran keluarga, sekolah, dan masyarakat dalam pembentukan karakter berkualitas. Edukasia: Jurnal Penelitian Pendidikan Islam, 8(2). http://dx.doi.org / 10.21043/edukasia.v8i2.75 7

Suharsono. 2003. Membelajarkan Anak Dengan Cinta. Jakarta: Inisiasi Press

------------. (2004). Mencerdaskan Anak. Jakarta: Inisiasi Press. Sunadi, L. 2013. Pengaruh motivasi belajar dan pemanfaatan fasilitas belajar terhadap prestasi belajar siswa pada mata pelajaran ekonomi kelas XI IPS di SMA
Muhammadiyah 2 Surabaya. Jurnal Pendidikan Ekonomi (JUPE), 1(3).

Tuti, A. 2015. Sistem pembelajaran berbasis teknologi informasi dan komunikasi. S o s i a $l B$ u d a y a: Media Komunikasi Ilmu -Ilmu Sosial dan Budaya, 12(1).

Zulkarnain, W. 2013. Dinamika Kelompok Latihan Kepemimpinan Pendidikan. Jakarta: Bumi Aksara. 
Al-Mudarris : Jurnal Ilmiah Pendidikan Islam

p-ISSN: 2622-1993

Vol. 3, No. 1, Mei 2020, pp. 21-42

e-ISSN: 2622-1586 